\title{
Potential Bacterial Health Risk Posed to Consumers of Fresh Coconut (Cocos nucifera L.) Water
}

\author{
Adolf K. Awua, Edna D. Doe, Rebecca Agyare \\ Cellular and Clinical Research Centre, Radiological and Medical Sciences Research Institute, Ghana Atomic Energy Commission, \\ Accra, Ghana. \\ Email: a_awua@yahoo.com,dzidey@yahoo.com,rebecca.agyare@yahoo.com
}

Received May $18^{\text {th }}, 2012$; revised July $4^{\text {th }}, 2012$; accepted July $11^{\text {th }}, 2012$

\begin{abstract}
Coconut (Cocos nucifera L.) water is a refreshing drink consumed mostly directly from the fruit. However, in recent times, consumers in Accra prefer to have it transferred into plastic bags for later consumption; this favours a high risk of bacterial contamination. Since it is rich in nutrient, it may become unwholesome with possible high bacteria loads. However, its use for managing and preventing diarrhoeal diseases and the report that coconut water contains antibacterial proteins, suggests a bacteria growth inhibition potential for it. Therefore, the propensity of fresh coconut water to support the growth of two pathogenic bacteria was studied. Using mostly optical density measurement, and where possible, growth parameters and bacteria loads were estimated for the growth of two gram negative bacteria in fresh, stored and sterilized coconut water, and also in Luria-Bertani (LB) broth as a control. The study revealed that fresh coconut water is a drink favourable for the survival and growth of Escherichia coli, and Klebsiella pneumoniae. It supported the growth of these bacteria, recording lag times of $101.4 \pm 1.00$ minutes for E. coli and $154.8 \pm 0.45$ minutes for K. pneumoniae, and high loads of viable cells of $\sim 2.27 \times 10^{8} \mathrm{cfu} / \mathrm{mL}$ and $>2.83 \times 10^{8} \mathrm{cfu} / \mathrm{mL}$ at the stationary phase for E. coli and $K$. pneumoniae respectively. These and other growth parameters in coconut water were comparable to those in Luria-Bertani (LB) broth medium. However, when autoclaved, gamma irradiated or stored at $4^{\circ} \mathrm{C}$ for two weeks or more, the growth of these bacteria becomes extremely limited. Fresh coconut water will support the growth of these bacteria to high and infective load of viable cell if it becomes contaminated with and is kept at ambient temperatures for two or more hours. Thus, it will be safer to consume coconut water directly from the fruit, since there is a high risk for bacteria contamination associated with the transfer and storage in other containers.
\end{abstract}

Keywords: Coconut Water; Bacterial Growth Curves; Health Risk

\section{Introduction}

Out breaks of pathogenic bacterial infection and related diseases such as cholera and bacterial gastroenteritis are know to be transmitted through food and drinking water. In most countries, food handlers and food from road side vendor constitute the greatest risk for bacterial infections. Earlier this year (2011), an epidemic of cholera in five regions of Ghana was reported to have affected more than 6000 persons and lead to more than 80 deaths as at August 2011 [1]. Most of the cases were reported after the patients had consumed food or water obtained from food stands vendors located in street corners. The burden of other food borne bacterial infection such as that of $E$. coli have not yet been fully investigated and/or reported for Ghana.

In Accra, green coconut (Cocos nucifera L.) fruit stands are common along roads, as is expected in most coconut producing developing countries. The coconut fruit is sold openly while the coconut water and endosperm are mostly consumed fresh and directly from the fruit. However, in recent times, some consumers prefer to transfer these into plastic bags so that it may be transported or/and stored refrigerated for several hours before consumption. During this transfer, the water is most likely to be exposed, with a high possibility of contact with pathogenic bacteria.

The water of the green coconut (Cocos nucifera L.) fruit, also referred to as coconut juice, is a natural drink common in the tropics [2-4]. It is a clear, colourless, sweet, naturally flavoured slightly acidic drink. Decades of research have shown that coconut water is a rich source of nutrient, among which are essential amino acids (lysine, leucine, cystine, phenylalanine, tyrosine, histidine, and tryptophan), palmitic and oleic acids and dietary minerals $[4,5-7]$. Others minerals such as iron, zinc and manganese are available at appreciable levels $[5,8]$. The principal sugars in coconut water are glucose, fruc- 
tose, and sucrose, while tartaric, citric and malic acids are its abundant organic acids. It also contains vitamin $\mathrm{B}_{1}$, vitamin $\mathrm{B}_{2}$ and vitamin $\mathrm{C}[2,6]$.

Limited literature is available that indicates that coconut water is able to synthesize different antimicrobial peptides with diverse properties and mechanisms of actions including an activity against human pathogenic bacteria [9]. Since coconut water is sterile and stable inside the fruit, it has been used for short-term intravenous hydration of patients. It has also been used in the treatment of child and adult diarrhoea, gastroenteritis and in protecting against gastrointestinal tract infections [9]. However, due to external contamination by microorganisms, in relation to how it is extracted, it may become unwholesome within a day, with bacteria load in the order of $10^{6}$ per $\mathrm{ml}[10,11]$. The nutritional content and medical use of coconut water are suggestive of a bacteria growth promoting and growth limiting potential, respectively.

In spite of these seemly opposing potentials of coconut water, there are limited reports of the survival and growth of pathogenic bacteria in coconut water. A report by Walter et al., [4] in modelling the growth of Listeria monocytogenes in coconut water presented data to show that fresh coconut water was favourable for the survival and growth of L. monocytogenes and that refrigeration at $10^{\circ} \mathrm{C}$ or $4^{\circ} \mathrm{C}$ retarded, but did not inhibit, growth of the bacterium in green coconut water.

With these in mind and the availability and high consumer base of coconut water in Ghana, we designed a study to investigate the bacterial health risk posed to consumers of coconut water sold along street corners in Madina, a suburb of Accra. Before assessing the possibility of coconut water serving as a means of transmitting bacteria infection, we sort to first assess the survival and growth of E. coli and K. pneumoniae in freshly extracted and stored coconut water. We also investigated if coconut water could sustain high and infective bacterial loads during the growth period. In this report, we present data on the growth parameters of selected pathogenic bacteria in fresh, stored and sterilize (autoclaved and gamma irradiated) coconut water. Also, presented are data on the bacterial loads at the end of the lag phase and during the stationary phase of growth.

\section{Method}

\subsection{Coconut Water Extraction and Characteristics}

A description of sample collection (coconut fruit), extraction and sterilisation of the coconut water and analyses of its characteristic of interest have been previously reported [12]. The coconut water stored at $4{ }^{\circ} \mathrm{C}$ for two weeks was used in this study.

\subsection{Bacteria Cultures}

The sterility of the coconut water samples were tested by inoculating sterile LB broth with $50 \mu \mathrm{L}$ aliquot followed by incubation in a Grant OLS 200 water-bath shaker at $37^{\circ} \mathrm{C}$ and $125 \mathrm{rpm}$ for 24 hours. Also, $5 \mathrm{~mL}$ aliquot of these coconut water samples was incubated at $37^{\circ} \mathrm{C}$ for 24 hours.

Aliquots of diluted liquid cultures of two standard strains, Klebsiella pneumonia ATCC 33495, and Escherichia coli ATCC 25922, were aseptically sub-cultured on a nutrient agar plate followed by an overnight incubation at $37^{\circ} \mathrm{C}$. From the plates with isolated colonies, a colony each of the bacteria was used to inoculate separate $30 \mathrm{~mL}$ portions of Luria Bertani (LB) broth as well as those of fresh, stored, autoclaved and irradiated coconut water samples. The cultures were incubated in a Grant OLS 200 water-bath shaker at $37^{\circ} \mathrm{C}$ and $125 \mathrm{rpm}$. The optical density (OD) at $686 \mathrm{~nm}$ for each was measured (UV-VIS 1210 Spectrophotometer, Shimadzu Corp., Columbia MD, USA) at intervals of 30 minutes for not more than 6 hours. Measurements of optical density were in triplicates and each culture was repeated at least once. At each time of measuring the OD of the cultures, 100 $\mu \mathrm{L}$ of the cultures were recovered and diluted to between $10^{-2}$ and $10^{-6}$ in phosphate buffered saline. Viable cell counts were obtained by spreading $100 \mu \mathrm{L}$ of the diluted culture on plate count agar (PCA); the standard total aerobic plate count (TAPC) method. The PCA plates were incubated at $37^{\circ} \mathrm{C}$ for 24 hours and the number of colonies counted. Bacteria load was reported as number of colony forming units per $\mathrm{mL}(\mathrm{cfu} / \mathrm{mL})$.

\subsection{Statistical Analysis}

MS Excel microcomputer software (Microsoft Corporation) was used to obtain descriptive statistics (averages, standard error etc) and percentage changes (increases and decreases) in measured parameters. The student t-test was used to analyse for statistical significance in the differences in lag time, growth rate and maximum growth for LB broth and fresh coconut water.

\section{Results}

There were no growth on the nutrient agar plates and the coconut water-inoculated LB broth remained as clear as the non-inoculated LB controls.

$E$. coli survived in the fresh coconut water studied and recorded growth curves that followed the trend expected for a normal bacteria growth curve. The lag time, defined as the intercept of the exponential phase, for the growth of $E$. coli in LB, fresh and autoclaved coconut water were $97.3 \pm 0.2 \mathrm{~min} ., 101.4 \pm 1.00 \mathrm{~min}$. and $51.4 \pm 0.028$ min. respectively (Figure $\mathbf{1}$ and Table 1). These were 


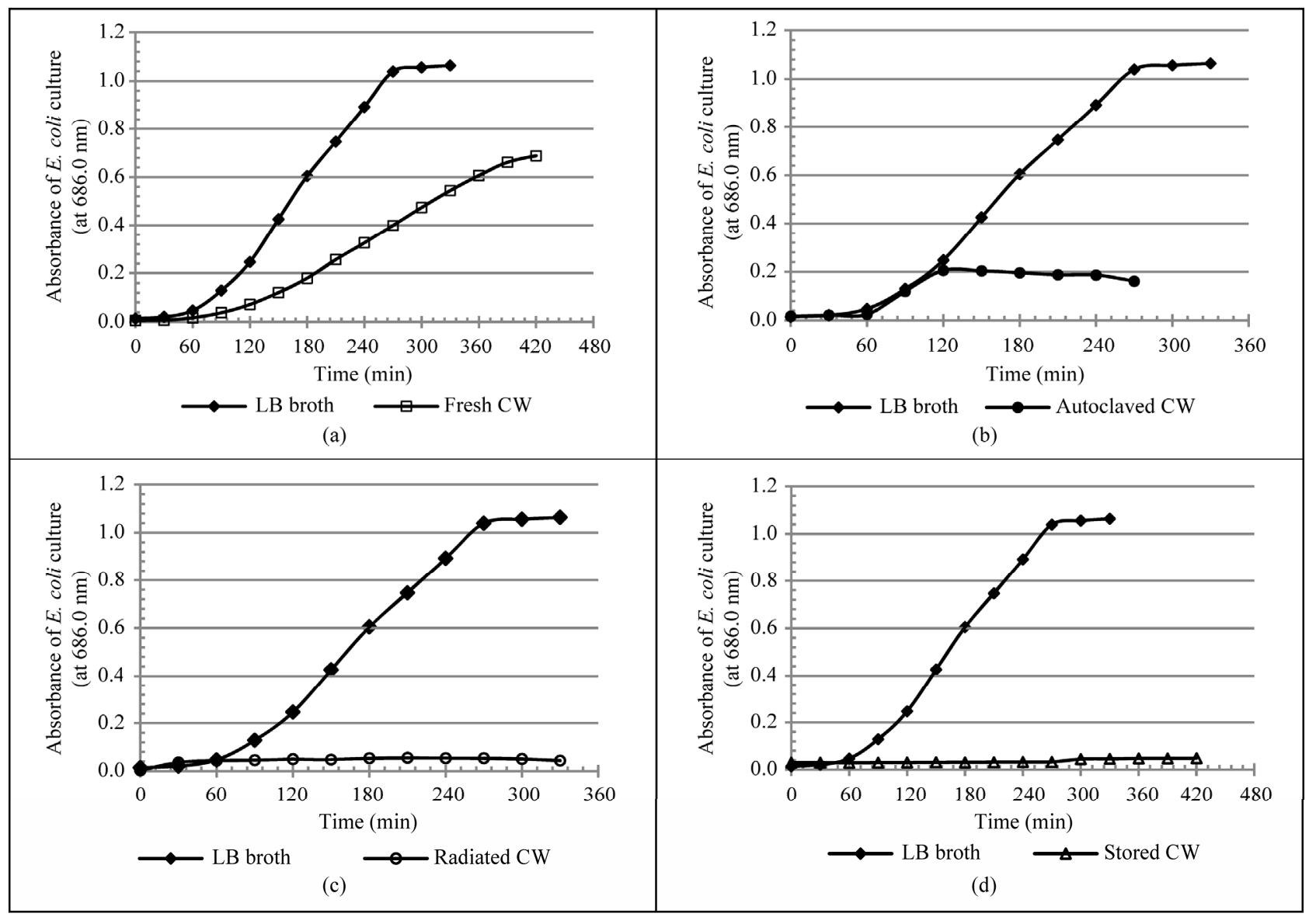

Figure 1. Growth curves of $E$. coli cultures in various media. Growth curves of LB broth and that of (a) Fresh coconut water; (b) Autoclaved coconut water; (c) Irradiated coconut water and (d) Stored coconut water. An isolated single colony of $E$. coli was transferred to $30 \mathrm{~mL}$ of each medium and incubated at $37^{\circ} \mathrm{C}$. The growth of the bacteria was followed spectrophotometrically by the measurement of optical density $(\mathrm{OD})$ at $686 \mathrm{~nm}$.

significantly different $(p<0.05)$. Growth rate was defined as the slope of the exponential growth phase of a growth curve. A comparison of the different growth rates of $E$. coli (Figure 1) shows a slightly higher rate in autoclaved coconut water $(0.181 \pm 0.0005$ OD units/h) as compared to that in fresh coconut water $(0.142 \pm 0.0004$ OD units $/ \mathrm{h}$ ). However, both were much lower than the growth rate of E. coli in LB broth $(0.463 \pm 0.002 \mathrm{OD}$ units $/ \mathrm{h}, p<0.05)$. The average of the OD at a stationary growth phase was defined as the measure of maximum growth of the bacteria. In this regard, large differences ( $p$ $<0.05$ ) were observed in the maximum growth of $E$. coli in LB broth, fresh and autoclaved coconut water (Figure 1 and Table 1).

Specifically, LB broth recorded $1.021 \pm 0.001$ OD units, fresh coconut water recorded $0.682 \pm 0.001$ OD units and autoclaved coconut water recorded $0.195 \pm$ 0.001 OD units. However, the growth of E. coli in irradiated and stored coconut water was greatly limited with no indication of any increase or exponential growth.

With regards to the growth of $K$. pneumoniae, the normal bacteria growth curve was observed only for LB broth and fresh coconut water (Figure 2). The lag times for the growth of $K$. pneumoniae in LB broth and fresh coconut water were $171.2 \pm 0.17 \mathrm{~min}$. and $154.8 \pm 0.45$ min. respectively; the difference of about $17.0 \mathrm{~min}$. was found to be significant, $(p<0.05$, Table 2). The growth rate of $K$. pneumoniae in LB broth $(0.350 \pm 0.0019$ OD units/h) was significantly higher than that in fresh coconut water $(0.216 \pm 0.002 \mathrm{OD}$ units $/ \mathrm{h})$ by about $61.7 \%$ ( $p$ $<0.05$ ) as shown in Table 2. Although the exact maximum growth of $K$. pneumoniae in fresh coconut water was not attained within the duration of incubation used for the study, the maximum growth of $K$. pneumoniae in LB was lower than that predictable or that expected in fresh coconut water based on the growth curve (Figure 2). Growth of $K$. pneumoniae in stored coconut water was stationary for about 120 minutes after which a marginal increase in growth rate was observed. A stationary growth rate followed, with a reduction at the end. However, growth in radiated coconut water and autoclaved coconut water was stationary throughout the period of 


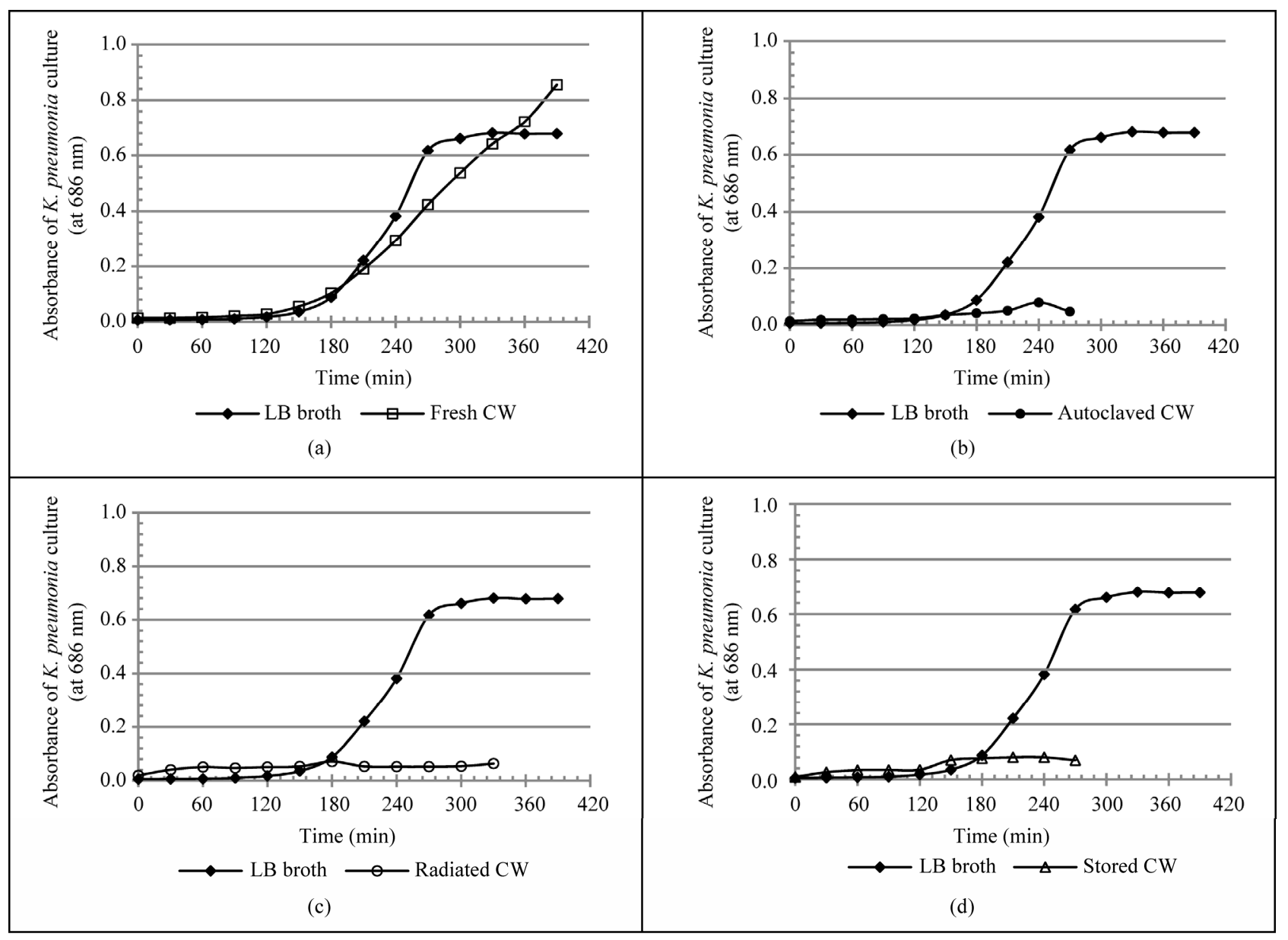

Figure 2. Growth curves of $K$. pneumoniae cultures in various media. Growth curves of LB broth and that of (a) Fresh coconut water; (b) Autoclaved coconut water; (c) Irradiated coconut water and (d) Stored coconut water. An isolated single colony of $K$. pneumoniae was transferred to $30 \mathrm{~mL}$ of each medium and incubated at $37^{\circ} \mathrm{C}$. The growth of the bacteria was followed spectrophotometrically by the measurement of optical density (OD) at $686 \mathbf{~ n m}$.

incubation.

\section{Discussion}

The absence of colonies on nutrient agar plates and the maintenance of the optical density or turbidity of the coconut water inoculated LB broth after 24 hours of incubation indicate that the coconut water used was sterile Furthermore, the fact that there were no changes in turbidity of non-inoculated coconut water controls used during the subsequent growth studies, further confirmed the sterility of the coconut water used in the study. The variations in characteristics of the studied coconut water have been previously explained [12].

The different lag times for the growth of E. coli in LB broth, fresh and autoclaved coconut water (Figure 1 and Table 1), indicates that E. coli adapts better to autoclaved coconut water than it does to LB broth and much better than to fresh coconut water. In other words, E. coli cells took-up nutrients, switch on their replication ma- chinery and their growth in volume were all faster in autoclaved coconut water than they were in both LB broth and fresh coconut water. The longest adaptation/lag time with respect to fresh coconut water, could have been influenced by factors such as low nutrient bioavailability, the presence or actions of proteins with antibacterial properties and complex enzyme products that have been reported to be present in it [9]. This may therefore imply that autoclaving may have resulted in either an increase in nutrient bioavailability, reduction or the destruction of these proteins and enzyme products resulting in the shorter lag time for $E$. coli in it. This assertion is supported by reports that show that during autoclaving, the biologic quality (quantity, structure and function) of proteins are often reduced or lost due to reactions involving the amino acid residues of these proteins and sugars [1315]. It must however be stated that the significance of these possible contributions cannot be determined by the results of this study.

The longer lag time for the growth of E. coli in fresh 
Table 1. Growth parameters of $E$. coli in LB broth and coconut water.

\begin{tabular}{ccccc}
\hline \multicolumn{2}{c}{$\begin{array}{c}\text { Parameters } \\
\text { (E. coli) }\end{array}$} & LB broth & Fresh CW & Autoclaved CW \\
\cline { 2 - 5 } & Mean \pm SE \\
\hline $\begin{array}{c}\text { Lag time/ } \\
\text { intercept }\end{array}$ & min. & $97.3 \pm 0.2$ & $101.4 \pm 1.00$ & $51.4 \pm 0.028$ \\
$\begin{array}{c}\text { Growth } \\
\text { rate/slope }\end{array}$ & OD/h & $0.463 \pm 0.002$ & $0.142 \pm 0.0004$ & $0.181 \pm 0.0005$ \\
& Ave. OD. & $1.54 \times 10^{8}$ & $4.73 \times 10^{7}$ & $6.03 \times 10^{7}$ \\
$\begin{array}{c}\text { Maximum } \\
\text { growth }\end{array}$ & at SP & $1.021 \pm 0.001$ & $0.682 \pm 0001$ & $0.195 \pm 0.0004$ \\
& cfu/mL & $3.4 \times 10^{8}$ & $2.27 \times 10^{8}$ & $6.5 \times 10^{7}$ \\
\hline
\end{tabular}

From Figure 1, the growth rate was defined as the slope of the tangent to the exponential growth phase, the time axis intercept of which was defines as the lag time. The average of the optical density (OD) at the stationary phases was defined as the maximum growth $\mathrm{CW}=$ coconut water, $\mathrm{SP}=$ stationary phase.

Table 2. Growth parameters of $K$. pneumoniae in LB and fresh coconut water.

\begin{tabular}{cccc}
\hline & & \multicolumn{2}{c}{ Mean \pm SE } \\
\cline { 3 - 4 } Parameters (K. pneumoniae) & LB broth & $\begin{array}{c}\text { Fresh coconut } \\
\text { water }\end{array}$ \\
\hline $\begin{array}{c}\text { Lag time/ } \\
\text { intercept }\end{array}$ & min. & $171.2 \pm 0.17$ & $154.8 \pm 0.45$ \\
$\begin{array}{c}\text { Growth } \\
\text { rate/slope }\end{array}$ & OD/h & $0.350 \pm 0.0019$ & $0.216 \pm 0.002$ \\
$\begin{array}{c}\text { Maximum } \\
\text { growth }\end{array}$ & Ave. OD. at SP & $0.666 \pm 0.0001$ & $>0.850$ \\
\hline
\end{tabular}

The growth rate was defined as the slope of the exponential growth phase, the time axis intercept of which was defines as the lag time. The average of the $\mathrm{OD}$ at the stationary phase was defined as the maximum growth (Figure 2).

coconut water imply that should it be contaminated shortly after its extraction, the early consumption of the water (before one and half hours), will most likely avert the risk of bacterial infection. In other words, consuming the coconut water directly from the fruit has the lowest potential risk of bacterial infection.

With regards the exponential growth phases of $E$. coli, described by its growth rate, a comparison of LB broth to both fresh and autoclaved coconut water, revealed a 3 fold rate in LB broth. This would imply that the internal nutrient concentration of $E$. coli cells in LB broth at the point of dynamic nutrient equilibrium was higher than those in both fresh and autoclaved coconut water. Factors such as differences in nutritional composition, initial $\mathrm{pH}$ and the extent of $\mathrm{pH}$ changes during the exponential growth period were expected to have contributed to the differences in growth rate. It is worth noting that the initial $\mathrm{pH}$ of LB broth was 7.0, optimal for the growth of $E$. coli (survive between $\mathrm{pH} 4.5$ and 9.0), while those for fresh and autoclaved coconut water were slightly below the optimal (6.5 and 5.0 respectively). As will be discussed later, autoclaving also leads to the loss of nutriaents, implying a low internal nutrient concentration at the point of dynamic nutrient equilibrium resulting in the slower growth rate in autoclaved coconut water compared to that in fresh coconut water.

This growth rate of $E$. coli in fresh coconut water indicates that fresh coconut water can support an average increase in the number $E$. coli cells up to a high of $4.73 \times$ $10^{7} \mathrm{cfu}$ per hour, which is a fast rate. Therefore, storing fresh coconut water at ambient temperature for more than 120 minutes (an hour longer than the lag time) increases the bacterial health risk of the consumer if the water was contaminated during or after extraction and transfer to other containers. Potentially high and infective loads of $E$. coli can be attained in fresh coconut water.

The stationary phase of growth of E. coli was described by the maximum growth it attained. The lower value in autoclaved coconut water indicates that nutrients became limiting faster/earlier relative to those in LB broth and fresh coconut water. As mentioned earlier, autoclaving leads to loss of nutrients. Autoclaving has been shown to result in the reduction (in amount) of free amino acids (particularly tyrosine, phenalanine, cyteine, lysine and methionine), crude proteins, sugars and some mineral nutrients $\left(\mathrm{Mg}^{+2}, \mathrm{PO}_{4}^{-}, \mathrm{Na}^{+}, \mathrm{K}^{+}\right.$, and $\left.\mathrm{Ca}^{+2}\right)$ in fruit juices and bacteria growth media [15-17]. This is because at such high temperatures and pressure, amino acids (both free and as protein residues) react with carbohydrates, particularly sugars, to form complex biomolecules that are often not bio-available to bacteria [13]. It is worth noting as reported earlier [12] that the amount of total carbohydrate in fresh coconut water was higher than that of autoclaved coconut water, although the difference was not significant. This maximum growth attained by $E$. coli in fresh coconut water, estimated to be between $5.2 \times 10^{8} \mathrm{cfu} / \mathrm{mL}$ and $5.6 \times 10^{8} \mathrm{cfu} / \mathrm{mL}$, indicates that fresh coconut water is able to support the growth of E. coli to higher cell loads that is within the infective load of E. coli. During outbreaks, enteropathogenic, enterotoxigenic and enteroaggregative E. coli strains require loads between $10^{6}$ and $10^{8}$ to cause diarrhoea [18]. These therefore suggests that the longer the coconut water is stored the more it is a potential bacterial health risk to the consumers.

The other gram negative bacteria studied for its survival and growth in coconut water was $K$. pneumoniae. The trend in its growth and the growth parameters in LB broth and the different forms of coconut water were presented as Figure 2 and in Table 2. The shorter lag time for $K$. pneumoniae in fresh coconut water as compared to that in LB broth indicates that it adopts better in fresh 
coconut water. That is, it takes up nutrients, switches on its replication machinery and grows in volume as well as initiates exponential growth faster in fresh coconut water than in LB broth. It is a well established fact that the lag phase of the growth of a bacterium depends both on the medium of growth and the growth requirements of the bacterium in question. Therefore, it can be said that the requirement for the initiation of the growth of K. pneumoniae are better met by fresh coconut water than LB broth. The influence of $\mathrm{pH}$ difference can be discounted since both $\mathrm{pH}$ values (6.5 for fresh coconut water and 7.0 for LB broth) were within the range of the optimal $\mathrm{pH}$ for the growth of K. pneumoniae (optimal $\mathrm{pH}$ for the growth K. pneumonia is about 6.8).

This lag time in fresh coconut water imply that contaminating $K$. pneumoniae cells will take about two and half hours $(2.5 \mathrm{~h})$ to start multiplying and therefore consumers of coconut water will be increasing their risk of $K$. pneumoniae infection if they keep coconut water purchased from vendors with the possibility of contamination for more than two hours before consumption.

Concerning the growth rate of $K$. pneumoniae during the exponential phase of growth, the slightly lower value obtained in fresh coconut water indicates that the internal concentration of nutrients in the cells of K. pneumoniae in coconut water were slightly lower than that in LB broth after the attainment of the so called nutrient dynamic equilibrium. This growth rate of $K$. pneumoniae in fresh coconut water suggests that fresh coconut water will be able to support a high average increase in the number of cells of K. pneumoniae that is up to $7.2 \times 10^{7}$ $\mathrm{cfu} /$ hour. Therefore, storing fresh coconut water at ambient temperature for more than 3.5 hours (one hour more than the lag time) increases the risk of acquiring high loads of contaminating $K$. pneumoniae cells every hour. Such high loads are potentially infectious if consumed at a time.

The maximum growth of $K$. pneumoniae in LB broth was lower than its potential maximum growth in fresh coconut water. This higher maximum growth in fresh coconut water indicates that more nutrients were available to sustain the dynamic nutrient equilibrium between the cells of $K$. pneumoniae and fresh coconut water. On the other hand, that in LB broth became limiting resulting in the stationary growth due probably to a reducing internal nutrient concentration. Other factors such the difference in the amount metabolic waste and the magnitude of $\mathrm{pH}$ change in both media contributed to the difference in the maximum growth of $K$. pneumoniae. The fact that the maximum growth of $K$. pneumoniae in LB broth, estimated to be between $8.16 \times 10^{7}$ and $2.2 \times 10^{8}$ $\mathrm{cfu} / \mathrm{mL}$, was lower than the potential maximum growth for it in fresh coconut water $\left(>2.83 \times 10^{8} \mathrm{cfu} / \mathrm{mL}\right)$, imply that fresh coconut water is able to support the growth of high loads above $\left(\sim 3.0 \times 10^{8} \mathrm{cfu} / \mathrm{mL}\right)$ of $K$. pneumoniae. This high loads further supports the potential of bacteria risk of consuming coconut water transfer and store in containers with the possibility contamination.

Although the possible contributions of growth inhibitory antibacterial peptides and other growth limiting substances reported to be present in coconut $[3,9,15]$ cannot be evaluated with the results of this study, it is clear that these would have a minimal contribution in influencing the growth of $K$. pneumoniae in contaminated coconut water.

The inhibition of growth of both bacteria in stored, gamma irradiated, and autoclaved coconut water could be due to one or a combination of the following; the resultant acidic $\mathrm{pH}$, high increase in free radical concentration, lost of nutrient or the presence of anti-bacterial polyphenols or/and $O$-quinone.

Polyphenols have been shown to be toxic with the more oxidised forms being highly inhibitory to the growth of bacteria [19]. Also, quinones are reported as a source of stable free radicals that may be inhibitory to bacteria growth by their ability to irreversibly bind to nucleophilic amino acids of bacteria cell membrane and cell wall proteins and polypeptides [19]; nutritional proteins and free amino acids may be rendered unavailable to bacteria by this irreversible complex formation $[13,17]$.

In these forms of coconut water, the presence of polyphenols and $\mathrm{O}$-quinones, is indicated by the resultant yellow colour; These are formed by the reactions of hydroxylated amino acids, catalysed by the innate heat stable polyphenol oxidases and pereoxidases and by free radicals, in the presence of oxygen [20].

The role of persistent free radicals, specifically in gamma irradiation coconut water, is suggested by data that shows that high gamma radiation doses resulted in high amounts of free radical generation in fruit juices. Irradiation doses of between $4.23 \mathrm{kGy}$ and $8.71 \mathrm{kGy}$ resulted in progressive loss of antioxidant activity during storage for up to 21 days [21]. The contribution of the acidic nature $(\mathrm{pH}$ of 4.5$)$ of the three forms of coconut water to the inhibition of growth is strongly suggested by the fact that the lower limit for the survival of the two bacteria studied is about 4.0 .

There is therefore the need to further study the contribution of all this possible factors to the inhibition of the growth of E. coli and K. pneumoniae in these forms of coconut water. A study that will adjust or control for the initial $\mathrm{pH}$, determine the free radical and nutritional content of the three forms of coconut water will help to throw more light on the growth inhibition.

\section{Conclusion}

Data presented by this study quantifies the capacity of 
fresh coconut water to support the survival and growth of $E$. coli and $K$. pneumoniae, and shows that these are comparable to those in LB broth. Specifically, the cell loads of E. coli and K. pneumoniae in fresh coconut water were observed to be high and within infective ranges. These high loads, coupled with the risk of contamination, suggests a high tendency for the acquisition of these bacteria infections through the consumption of coconut water transferred from the fruit and stored at ambient temperature for up to 3 hours, should it be contaminated by these bacteria. We recommend the consumption of coconut water directly from the fruit unless a new technology for packaging coconut water in Ghana is introduced.

\section{Acknowledgements}

The authors are thankful to their senior colleagues for their useful suggestions and support for this study. Specifically we are grateful to Mr. Oti Kwasi Gyamfi (Celluar and Clinical Research Centre, GACE) and Mr. David Bansa (Nutrition Research Centre, GACE). We are also thankful to the following for their assistance; Miss Margaret Dadzie (Applied Radiation Biology Centre, GACE), Mr. Kofi Bedzera (CCRC, GACE), Mr. Maxwell Ofori Appiah and Mr. Jonathan Okai Armah (Gamma Irradiation Facility, GAEC), and Sylvester Kaminta of the Center for Scientific Research into Plant Medicine, Ghana.

The authors declare that they have no competing interests.

\section{REFERENCES}

[1] R. Kelly, "Ghana-Cholera Outbreaks in 2011," 2011. http://www.flutrackers.com/forum/showthread.php?t=159 173

[2] M. DebMandal and S. Mandal, "Coconut (Cocos nucifera L.: Arecaceae): In Health Promotion and Disease Prevention," Asian Pacific Journal of Tropical Medicine, Vol. 1, 2011, pp. 241-247. doi:10.1016/S1995-7645(11)60078-3

[3] A. M. Fonseca, F. J. Q Monte, M. da Conceic and F. de Oliveiraa ão, "Coconut Water (Cocos nucifera L.)-A New Biocatalyst System for Organic Synthesis," Journal of Molecular Catalysis B: Enzymatic, Vol. 57, 2009, pp. 78-82. doi:10.1016/j.molcatb.2008.06.022

[4] E. H. M. Walter, D. Y. Kabuki, L. M. R. Esper, A. S. Sant'Ana and A. Y. Kuaye, "Modelling the Growth of Listeria monocytogenes in fresh Green Coconut (Cocos nucifera L.) Water," Food Microbiology, Vol. 26, 2009, pp. 653-657. doi:10.1016/j.fm.2009.04.003

[5] D. Campbell-Falck, T. Thomas, T. M. Falck, N. Tutuo and K. Clem, "The Intravenous Use of Coconut Water," American Journal of Emergency Medicine, Vol. 18, No. 1, 2000, pp. 108-111. doi:10.1016/S0735-6757(00)90062-7
[6] U. Santoso, K. Kubo, T. Ota, T. Tadokoro and A. Maekawa, "Nutrient Composition of Kopyor Coconuts (Cocos nucifera L.)," Food Chemistry, Vol. 57, No. 2, 1996, pp. 299-304. doi:10.1016/0308-8146(95)00237-5

[7] A. G. Pue, W. Riva, K. Sundarao, C. Kaluarin and K. Singh, "Preliminary Studies on Changes in the Coconut Water during Maturation of the Fruit," Science in New Guinea, Vol. 18, No. 2, 1992, pp. 81-84.

[8] A. Jayalakshmy, C. Arumughan, C. S. Narayanan and A. G. Mathew, "Changes in the Chemical Composition of Coconut Water during Maturation," Journal of Food Science and Technology, Vol. 23, No. 4, 1986, pp. 203-207.

[9] S. M. Mandal, S. Dey, M. Mandal, S. Sarkar, S. MariaNeto and O. L. Franco, "Identification and Structural Insights of Three Novel Antimicrobial Peptides Isolated from Green Coconut Water," Peptides, Vol. 30, No. 4, 2009, pp. 633-637. doi:10.1016/j.peptides.2008.12.001

[10] K. N. Matsui, J. A. W. Gut, P. V. de Oliveira and C. C. Tadini, "Inactivation Kinetics of Polyphenol Oxidase and Peroxidase in Green Coconut Water by Microwave Processing," Journal of Food Engineering, Vol. 88, No. 2, 2008, pp. 169-176. doi:10.1016/j.jfoodeng.2008.02.003

[11] K. V. Reddy, M. Das and S. K. Das, "Filtration ResisTances in Non-Thermal Sterilization of Green Coconut Water," Journal of Food Engineering, Vol. 69, 2005, pp. 381-385. doi:10.1016/j.jfoodeng.2004.08.029

[12] A. K. Awua, E. D. Doe and R. Agyare, "Exploring the Influence of Sterilisation and Storage on Some PhysicoChemical Properties of Coconut (Cocos nucifera L.) Water," BMC Research Notes, Vol. 4, 2011, pp. 451-454. doi:10.1186/1756-0500-4-451.

[13] J. G. Fox, "Nutrition: Decontamination of Diets," In: J. G. Fox, S. W. Barthold, M. T. Davisson, C. E. Newcomer, F. W. Quimby and A. L. Smith, Eds., The Mouse in Biomedical Research, 2nd Edition, Academic Press, Millbrae, 2007, pp. 362-364.

[14] Joint FAO/IAEA/WHO Expert Committee on the Wholesomeness of Irradiated Food, "Report of the Working Party on Irradiation of Food," WHO Technical Report Series, No.659, Geneva, 1981.

[15] E. N. Onyeike and T. T. Omubo-Dede "Effect of Heat Treatment on the Proximate Composition, Energy Values, and Levels of Some Toxicants in African Yam Bean (Sphenostylis stenocarpa) Seed Varieties," Plant Foods for Human Nutrition, Vol. 57, No. 3-4, 2002, pp. 223-231. doi:10.1023/A:1021833516234

[16] H. S. Rehan and B. G. Matapurka, "Tender Coconut Water: An Ideal Fluid for Parenteral Substitute," Journal of Institute of Medicine, Vol. 21, 1999, pp. 1-57.

[17] S. Divakaran, O. Decamp, J. J. Cody and W. G. Dominy, "Studies on Quality Changes in Shrimp Feeds Exposed to Gamma, E-Bem and X-Ray Irradiation," Journal of Aquaculture in the Tropics, Vol. 17, 2002, pp. 15551165.

[18] J. D. Greig, E. C. D. Todd and B. Michaels, "Infective Doses and Pathogen Carriage," Proceedings of the 2010 Food Safety Education Conference, Atlanta, 23-26 March 2010. 
http://www.fsis.usda.gov/PDF/Atlanta2010/Slides_FSEC JGreig_Doses.pdf

[19] M. M. Cowan, "Plant Products as Antimicrobial Agents," Clinical Microbiology Reviews, Vol. 12, No. 4, 1999, pp. 564-582.

[20] N. C. Murasaki-Aliberti, R. M. S. da Silva, J. A. W. Gut and C. C. Tadini, "Thermal Inactivation of Poly-Phenoloxidase and Peroxidase in Green Coconut (Cocos nu- cifera) Water," International Journal of Food Science \& Technology, Vol. 44, 2009, pp. 2662-2668.

doi:10.1111/j.1365-2621.2009.02100.x

[21] X. Fan, D. W. Thayer and A. P. Handel, "Nutritional Quality of Irradiated Orange Juice," Journal of Food Processing and Preservation, Vol. 26, No. 3, 2002, pp. 195 211. doi:10.1111/j.1745-4549.2002.tb00480.x. 